\title{
PENGELOLAAN SAMPAH DESA GUDANG TENGAH MELALUI MANAJEMEN BANK SAMPAH
}

\author{
Dewi Ariefahnoor $^{(1)}$ Nurul Hasanah ${ }^{(2)}$ Adhi Surya ${ }^{(3)}$

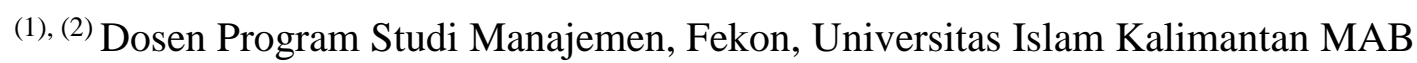 \\ ${ }^{(3)}$ Dosen Program Studi Teknik Sipil, Fatek, Universitas Islam Kalimantan MAB \\ Jalan Adhyaksa No.2, Banjarmasin, Kalimantan Selatan 70123 \\ E-mail: dewiariefahnoor@gmail.com/HP +6285391459394
}

\begin{abstract}
ABSTRAK
Bank sampah berdiri karena adanya keprihatinan masyarakat akan lingkungan hidup yang semakin lama semakin dipenuhi dengan sampah baik organik maupun anorganik. Sampah yang semakin banyak tentu akan menimbulkan banyak masalah, sehingga memerlukan pengolahan seperti membuat sampah menjadi bahan yang berguna. Pengelolaan sampah dengan sistem bank sampah ini diharapkan mampu membantu pemerintah dalam menangani sampah dan meningkatkan ekonomi masyarakat. Bank sampah adalah suatu tempat yang digunakan untuk mengumpulkan sampah yang sudah dipilah-pilah. Hasil dari pengumpulan sampah yang sudah dipilah akan disetorkan ke tempat pembuatan kerajinan dari sampah atau ke tempat pengepul sampah. Bank sampah dikelola menggunakan sistem seperti perbankkan yang dilakukan oleh petugas sukarelawan. Penyetor adalah warga yang tinggal di sekitar lokasi bank serta mendapat buku tabungan seperti menabung di bank. Tujuan utama pendirian bank sampah adalah untuk membantu menangani pengolahan sampah di Indonesia. Tujuan bank sampah selanjutnya adalah untuk menyadarkan masyarakat akan lingkungan yang sehat, rapi, dan bersih. Bank sampah juga didirikan untuk mengubah sampah menjadi sesuatu yang lebih berguna dalam masyarakat, misalnya untuk kerajinan dan pupuk yang memiliki nilai ekonomis. Bank sampah memiliki beberapa manfaat bagi manusia dan lingkungan hidup, seperti membuat lingkungan lebih bersih, menyadarkan masyarakat akan pentingnya kebersihan, dan membuat sampah menjadi barang ekonomis. Manfaat bank sampah untuk masyarakat adalah dapat menambah penghasilan masyarakat karena saat mereka menukarkan sampah mereka akan mendapatkan imbalan berupa uang yang dikumpulkan dalam rekening yang mereka miliki. Masyarakat dapat sewaktu-waktu mengambil uang pada tabungannya saat tabungannya sudah terkumpul banyak. Imbalan yang diberikan kepada penabung tidak hanya berupa uang, tetapi ada pula yang berupa bahan makanan pokok seperti gula, sabun, minyak dan beras. Bank sampah juga bermanfaat bagi siswa yang kurang beruntung dalam hal finansial, beberapa sekolah telah menerapkan pembayaran uang sekolah menggunakan sampah.
\end{abstract}

Kata kunci : Pengelolaan Sampah, Manajemen Bank Sampah, Desa Gudang Tengah

\begin{abstract}
The garbage bank was established because of the community's concern for the environment which was increasingly filled with both organic and inorganic waste. More and more garbage will certainly cause many problems, so it requires processing such as making waste into useful materials. Waste management with a garbage bank system is expected to be able to assist the government in handling waste and improving the community's economy. A garbage bank is a
\end{abstract}


place that is used to collect waste that has been sorted. The results of the collection of waste that has been sorted will be deposited to the place of making crafts from rubbish or to the garbage collectors. The garbage bank is managed using a system such as banking done by volunteer officers. The depositor is a resident who lives around the location of the bank and gets a savings book such as saving at a bank. The main purpose of establishing a waste bank is to help deal with waste management in Indonesia. The next goal of the waste bank is to make the community aware of a healthy, neat and clean environment. Garbage banks were also established to turn waste into something more useful in society, for example for crafts and fertilizers that have economic value. Garbage banks have several benefits for humans and the environment, such as making the environment cleaner, making people aware of the importance of cleanliness, and making waste an economic item. The benefit of the garbage bank for the community is that it can add to the people's income because when they exchange their waste they will get a reward in the form of money collected in the account they have. People can take money from their savings at any time when they have accumulated a lot of savings. Rewards given to savers are not only in the form of money, but also in the form of staples such as sugar, soap, oil and rice. The garbage bank is also beneficial for students who are less fortunate in financial matters, some schools have implemented tuition payments using garbage.

Keywords: Waste Management, Waste Bank Management, Gudang Tengah Village

\section{PENDAHULUAN}

\section{Latar Belakang}

Permasalahan lingkungan hidup yang terjadi di berbagai daerah pada saat ini adalah penurunan daya dukung lingkungan sebagai akibat rendahnya kesadaran masyarakat terhadap pentingnya pengelolaan lingkungan hidup. Hal ini dipicu oleh beberapa faktor, antara lain perubahan fungsi dan tatanan lingkungan, penurunan daya dukung lingkungan dan mutu lingkungan, tidak adanya keterpaduan pengelolaan sumber daya manusia, alam, dan buatan dalam pengelolaan lingkungan hidup antar berbagai pihak, kurang optimalnya pemanfaatan ruang kota, serta pencemaran lingkungan yang dihasilkan oleh adanya sampah. Perkembangan ilmu pengetahuan dan teknologi khususnya teknologi informasi pada saat ini sangat mendukung dalam penyediaan informasi lingkungan. Melalui teknologi intranet maupun internet arus informasi mengenai permasalahan lingkungan dan penanganannya dapat dilakukan dengan mudah.

Tujuan suatu sistem pengelolaan sampah ialah mengkonversi sampah menjadi bahan yang berguna secara efisien dan ekonomis dengan dampak lingkungan seminimal mungkin. Untuk melakukan konversi sampah diperlukan adanya informasi tentang karakter sampah, karakter teknis teknologi konversi yang ada, karakter pasar dari produk pengolahan, implikasi lingkungan, persyaratan lingkungan, dan ketersediaan dana.

Bank sampah berdiri karena adanya keprihatinan masyarakat akan lingkungan hidup yang semakin lama semakin dipenuhi dengan sampah baik organik maupun anorganik. Sampah yang semakin banyak tentu akan menimbulkan banyak masalah, sehingga memerlukan pengolahan seperti membuat sampah menjadi bahan yang berguna. Pengelolaan sampah dengan sistem bank sampah ini diharapkan mampu membantu pemerintah dalam menangani sampah dan meningkatkan ekonomi masyarakat. Bank sampah adalah suatu tempat yang digunakan untuk mengumpulkan sampah yang sudah dipilah-pilah. Hasil dari pengumpulan sampah yang sudah dipilah akan disetorkan ke tempat pembuatan kerajinan dari sampah atau ke tempat pengepul 
sampah. Bank sampah dikelola menggunakan sistem seperti perbankkan yang dilakukan oleh petugas sukarelawan. Penyetor adalah warga yang tinggal di sekitar lokasi bank serta mendapat buku tabungan seperti menabung di bank. Tujuan utama pendirian bank sampah adalah untuk membantu menangani pengolahan sampah di Indonesia. Tujuan bank sampah selanjutnya adalah untuk menyadarkan masyarakat akan lingkungan yang sehat, rapi, dan bersih. Bank sampah juga didirikan untuk mengubah sampah menjadi sesuatu yang lebih berguna dalam masyarakat, misalnya untuk kerajinan dan pupuk yang memiliki nilai ekonomis. Bank sampah memiliki beberapa manfaat bagi manusia dan lingkungan hidup, seperti membuat lingkungan lebih bersih, menyadarkan masyarakat akan pentingnya kebersihan, dan membuat sampah menjadi barang ekonomis. Manfaat bank sampah untuk masyarakat adalah dapat menambah penghasilan masyarakat karena saat mereka menukarkan sampah mereka akan mendapatkan imbalan berupa uang yang dikumpulkan dalam rekening yang mereka miliki. Masyarakat dapat sewaktu-waktu mengambil uang pada tabungannya saat tabungannya sudah terkumpul banyak. Imbalan yang diberikan kepada penabung tidak hanya berupa uang, tetapi ada pula yang berupa bahan makanan pokok seperti gula, sabun, minyak dan beras. Bank sampah juga bermanfaat bagi siswa yang kurang beruntung dalam hal finansial, beberapa sekolah telah menerapkan pembayaran uang sekolah menggunakan sampah.

\section{Identifikasi Masalah}

Berdasarkan data Desa Gudang Tengah dapat diidentifikasi sejumlah masalah sebagai berikut:

a. Banyaknya sampah rumah tangga dan sejenisnya Desa Gudang Tengah.

b. Masyarakat belum memahami tentang pemilahan sampah.

c. Masyarakat belum memahami tentang teknik pengolahan sampah yang benar.

d. Masyarakat belum memahami tentang nilai guna (ekonomis) sampah setelah dilakukan pengolahan melalui manajemen bank sampah.

\section{Rumusan Masalah}

Dari masalah-masalah tersebut dapat dirumuskan masalah sebagai berikut:

a. Bagaimanakah pengelolaan sampah Desa Gudang Tengah melalui manajemen Bank Sampah?

b. Kendala-kendala apa saja yang menghambat pengelolaan sampah Desa Gudang Tengah melalui manajemen Bank Sampah?

c. Bagaimanakah strategi dalam pengelolaan sampah Desa Gudang Tengah melalui manajemen Bank Sampah?

\section{Manfaat}

Manfaat yang diharapkan adalah:

a. Memberikan keterampilan kepada pengelola sampah dalam pengolahan sampah secara sederhana.

b. Sebagai wahana untuk meningkatkan pengetahuan dan wawasan dalam manajemen pengelolaan dan pengolahan sampah.

c. Sebagai forum untuk bertukar pikiran antara pihak pengelola sampah desa Gudang Tengah dengan perguruan tinggi dalam pengelolaan dan pengolahan sampah yang berwawasan lingkungan berbasis ilmu pengetahuan dan kemanfaatan sehingga dapat diterapkan.

d. Pembentukan bank sampah harus diintegrasikan dengan gerakan program 3R (ReuseReduce-Recycle) sehingga warga akan memperoleh manfaat langsung, tidak hanya secara ekonomi, juga terwujudnya kesehatan lingkungan, dengan kondisi komunitas yang bersih, hijau, nyaman, dan sehat. 
e. Bank sampah memberikan manfaat secara sosial dengan memperkuat kohesi sosial bagi keberadaan komunitas perempuan yang selama ini termarjinalisasi dalam konstruksi sosial budaya.

f. Manfaat lainnya secara ekonomis memberi dampak berupa tambahan penghasilan, dan manfaat untuk lingkungan dapat mengurangi timbulan sampah di Desa Gudang Tengah.

g. Alternatif solusi dalam mengatasi masalah sampah di Desa Gudang Tengah dengan pengembangan bank sampah merupakan kegiatan bersifat social engineering (Ridley-Duff dan Bull, 2011) yang mengajarkan masyarakat untuk memilah sampah serta menumbuhkan kesadaran masyarakat dalam pengolahan sampah.

\section{Batasan Masalah}

Batasan masalah hanya meninjau kondisi eksisting pengelolaan sampah DGT melalui manajemen Bank Sampah sebagai berikut:

a. Pengelolaan sampah masih manual yaitu pekerja sampah mengambil sampah dengan alat angkut sebuah tosa diantarkan ke TPS terdekat.

b. Belum memiliki pengelelolaan sampah yang baik dan

c. Belum melihat peluang ekonomi dari sisi pengelolaan sampah.

d. Peraturan Desa mengenai sampah desa belum begitu jelas dan detail memanyungi pengelolaan sampah.

e. Perlu adanya terobosan atau strategi dalam mengelola sampah Desa Gudang Tengah.

f. Perlu paradigma baru atau konsep dan prosedur pengelolaan sampah Desa Gudang Tengah melalui manajemen Bank Sampah. Dapat dilihat Gambar 1 dan Gambar 2.

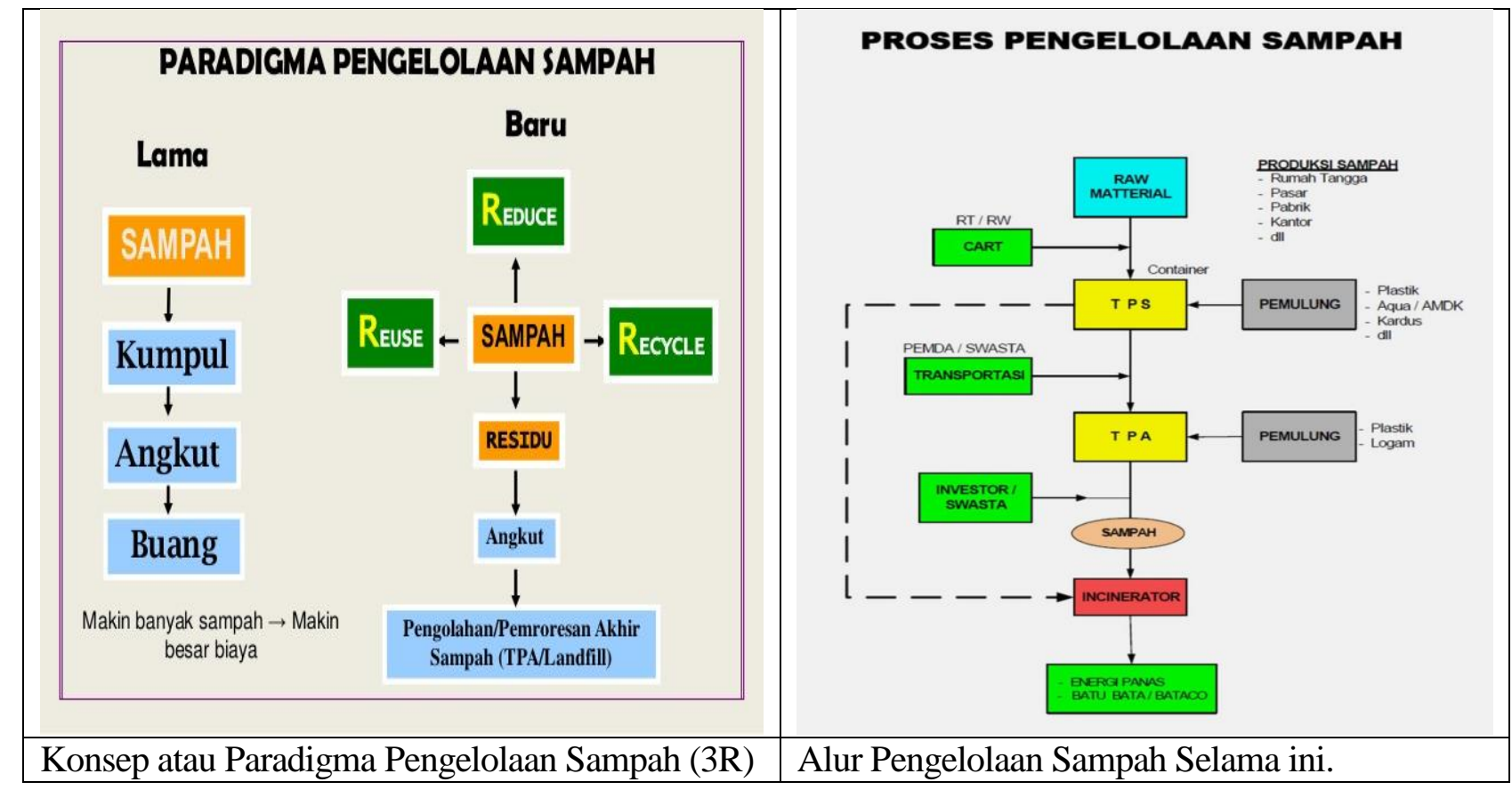

Gambar 1. Paradigma dan Proses Pengelolan Sampah

Sumber: www.google.com, 2019 


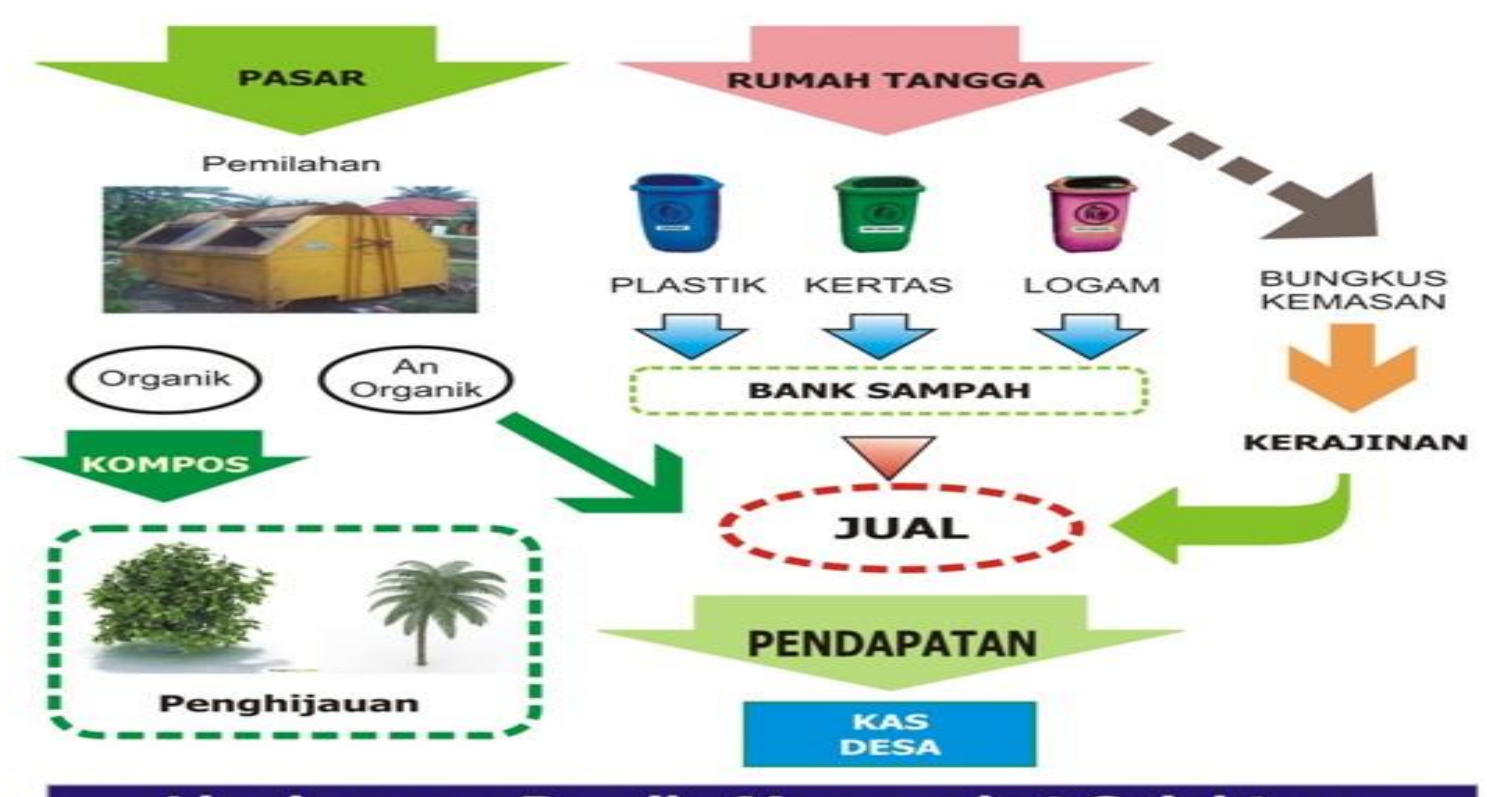

\section{Lingkungan Bersih, Masyarakat Sejahtera}

Gambar 2. Konsep Pengelolaan Sampah Desa Gudang Tengah

Sumber : www.google.com, 2019

\section{Sampah}

\section{TINJAUAN PUSTAKA}

Sampah merupakan suatu bahan yang terbuang atau dibuang dari sumber hasil aktivitas manusia maupun proses alam yang belum memiliki nilai ekonomis (Damanhuri, E., dkk., 2004). Menurut Undang-Undang Republik Indonesia Nomor 18 Tahun 2008 tentang pengelolaan sampah, sampah didefinisikan sebagai sisa kegiatan sehari-hari manusia dan/atau proses alam yang berbentuk padat. Secara umum sampah dapat diklasifikasikan menjadi 2, yaitu:

1. Sampah organik adalah sampah yang dapat terurai atau membusuk secara alamiah, misalnya sisa sayur-sayuran, buah-buahan, dan daun-daunan. Sampah ini merupakan bagian yang terbesar dari sampah rumah tangga $(+70 \%)$.

2. Sampah anorganik adalah sampah yang tidak dapat terurai atau membusuk secara alamiah dan memerlukan waktu yang sangat lama sekali untuk terurai, misalnya kertas, plastik, kayukayuan, kaca, kain, logam, dan lain-lain.

Disamping klasifikasi sampah organik dan anorganik, menurut UU RI No. 18 Tahun 2008, ada juga klasifikasi sampah spesifik. Sampah spesifik adalah sampah yang karena sifat, konsentrasi, dan/atau volumenya memerlukan pengelolaan khusus. Adapun sampah yang dikelola berdasarkan UU RI No. 18 Tahun 2008 terdiri atas:

1. Sampah rumah tangga, yaitu sampah yang berasal dari kegiatan sehari-hari dalam rumah tangga, tidak termasuk tinja dan sampah spesifik.

2. Sampah sejenis sampah rumah tangga, yaitu sampah yang berasal dari kawasan komersial, kawasan industri, kawasan khusus, fasilitas sosial, fasilitas umum, dan/atau fasilitas lainnya.

3. Sampah spesifik, yaitu meliputi:

a. sampah yang mengandung bahan berbahaya dan beracun (B3)

b. sampah yang mengandung limbah bahan berbahaya dan beracun

c. sampah yang timbul akibat bencana

d. puing bongkaran bangunan 
e. sampah yang secara teknologi belum dapat diolah

f. sampah yang timbul secara tidak periodik.

\section{Pengelolaan Sampah}

Pengelolaan sampah merupakan suatu proses yang diperlukan dengan dua tujuan sebagai berikut: a. Mengubah sampah menjadi material yang memiliki nilai ekonomis; b. Mengolah sampah menjadi material yang tidak membahayakan lingkungan dan masyarakat sekitar. Pengelolaan sampah yang dimaksud dalam penelitian ini adalah cara pengelolaan sampah yang tidak berguna lagi atau tidak terpakai dapat dipilah dan diolah menjadi barang yang memiliki nilai ekonomis dan ramah lingkungan. Kegiatan pengelolaan sampah meliputi penanganan di tempat, pengumpulan sampah, transfer dan transport, dan pengolahan. Yaitu: a. Penanganan di tempat (On place handling) adalah semua perlakuan terhadap sampah yang dilakukan sebelum sampah ditempatkan di lokasi tempat pembuangan, penanganan sampah di tempat dapat memberikan pengaruh yang signifikan terhadap penanganan sampah pada tahap-tahap yang meliputi pemilahan, pemanfaatan kembali, dan daur ulang dengan tujuan untuk mereduksi besarnya timbunan sampah; b.Pengumpulan (Collection) ini merupakan tindakan pengumpulan sampah dari sumbernya menuju ke tempat pembuangan sementara, dan pola pengumpulan sampah pada dasarnya dikelompokkan dalam dua pola, yakni pola individual dan pola komunal; c.Pengangkutan (Transfer atau Transport) merupakan usaha pemindahan yang sampah dari TPS menuju TPA dengan menggunakan truk sampah; d. Pengolahan (Processing) yaitu sampah dapat diolah tergantung pada jenis dan komposisinya, berbagai alternatif yang tersedia dalam proses pengolahan sampah diantaranya: 1 . Transformasi fisik, meliputi pemisahan sampah dan pemadatan yang bertujuan untuk memudahkan penyimpanan dan pengangkutan; 2 . Pembuatan kerajiann daur ulang, yaitu mengubah sampah kering (anorganik) menjadi barang yang mempunyai nilai ekonomis; 3. Pembuatan kompos (composting), yaitu mengubah melalui proses mikrobiologi menjadi produk lain yang dapat dipergunakan. Output dari proses ini adalah kompos dan bio gas.

\section{Manfaat Sampah}

Sampah merupakan masalah yang paling sering ditemui terutama di kota-kota besar, jika tidak diperlakukan dengan benar, sampah dapat menimbulkan masalah yang serius bagi manusia, oleh karenanya sampah harus diperlakukan dengan benar, dan ditangani secara serius dengan memanfaatkan sisa-sisa dari kegiatan manusia tersebut. Sebenarnya, sampah yang dianggap tidak berguna itu memiliki manfaat yang cukup besar untuk manusia. Berikut beberapa manfaat sampah untuk manusia diantaranya sebagai berikut:

a. Sebagai pupuk organik untuk tanaman. Limbah dari sampah organik dapat dijadikan pupuk penyubur tanaman dengan menyulap sampah menjadi kompos. Kompos dapat memperbaiki struktur tanah dengan meningkatkan kandungan organik tanah dan akan meningkatkan kemampuan tanah untuk mempertahankan kandungan air dalam tanah;

b. Sumber humus. Sampah organik yang telah membusuk dapat menjadi humus yang dibutuhkan untuk menjaga kesuburan tanah, serta menjadi sumber makanan yang baik bagi tumbuh-tumbuhan, meningkatkan kapasitas kandungan air tanah, mencegah pengerukan tanah, menaikkan foto kimia dekomposisi pestisida atau senyawa-senyawa organik racun;

c. Sampah dapat didaur ulang. Limbah sampah dari plastik dan kertas dapat didaur ulang menjadi berbagai barang yang bermanfaat. Seperti menjadi produk furniture yang cantik atau didaur ulang kembali menjadi bahan baku pembuatan produk plastik atau kertas. 


\section{Manajemen}

Setiap keberhasilan dari sebuah program kegiatan tidak terlepas dari pada manajemen. Manajemen adalah cara yang digunakan banyak orang dalam mengelola atau memeneg sesuatu sehingga menjadi teratur, terarah, dan terkendali. Cara kerja lebih sistematis dengan adanya manajemen.Begitu juga dengan manajemen pengelolaan sampah. Mulai dari tempat asal sampah berada sampai sampah dibuang ke Tempat Pembuangan Akhir. Dengan menggunakan konsep manajemen sebagai mana dijelaskan bahwa manajemen secara bahasa inggris yaitu " Manage" yang berarti; mengurus, mengelola, bagaimana mengendalikan, mengusahakan, dan memimpin. Sementara Manajemen secara etimologis adalah seni melaksanakan dan mengatur. Manajemen juga dipandang sebagai disiplin ilmu yang mengajarkan manusia bagaimana cara mendapatkan tujuan organisasi dalam upaya bersama dengan sejumlah orang atau sumber milik organisasi. Berikut ini, beberapa pengertian tentang manajemen menurut beberapa tokoh:

a. John M Echols dan Hasan Shadilly, menajemen adalah proses mengintegrasikan sumbersumber yang tidak berhubungan menjadi sistem total untuk menyelesaikan suatu tujuan.

b. Stoner, mengartikan bahwa manajemen merupakan proses perencanaan, pengorganisasian, pengarahan dan pengawasan usaha-usaha para anggota organisasi dan penggunaan sumber daya organisasi untuk mencapai tujuan organisasi yang telah ditetapkan.

c. Sementara George R. Terry mengemukakan pendapat tentang manajemen sebagai proses atau kerangka kerja yang melibatkan bimbingan atau pengarahan suatu kelompok orangorang kearah tujuan-tujuan organisasional maksud yang nyata.

d. Encylopedia of the Social Science ${ }^{1}$ menjelaskan manajemen sebagai sebuah proses yang pelaksanaan tujuan tertentu diselenggarakan dan diawasi.

e. Berbeda dengan pandangan Mary Parket Follet yang mengatakan manajemen sebagai sebuah seni atau management is an art.

f. Jadi setiap pekerjaan mampu diselesaikan baik dan terukur dengan menggunakan konsep manajemen mulai dari proses perencanaan, pengorganisasian, dan penggunaan sumber daya organisasi yang lain agar terwujud sebagaimana dijelaskan oleh James A.F. Stoner. Dengan kata lain, manajemen merupakan seni pencapaian tujuan yang setiap orang memiliki gaya dan caranya untuk melibatkan orang lain.

g. Sebagaiman mana sejalan dengan pendapat Wilson Bangun mengatakan manajemen sebagai rangkaian akivitas-aktivitas yang dikerjakan olehk anggota-anggota organisasi untuk mencapai tujuannya. ${ }^{2}$

h. Menurut Haiman, manajemen adalah fungsi untuk mencapai sesuatu melalui kegiatan orang lain dan mengawasi usahausaha individu untuk mencapai tujuan bersama.

i. Nickels dan Mc Hugh, manajemen adalah the process used to accomplish organizational goals through planning, organizing, directing, and controlling people and otherorganizational resources.

Maka berdasarkan pengertian tersebut dapat disimpulkan bahwa manajemen memiliki tiga unsur, pertama, adanya tujuan yang ingin dicapai. Kedua tujuan dicapai dengan mempergunakan kegiatan orang-orang lain. Ketiga, kegiatan orang lain harus dibimbing dan diawasi.

\footnotetext{
${ }^{1}$ M. Manullang, Dasar-dasar Manajemen, Yogyakarta: Gadjah Mada University Pers, 2015, hlm. 3.

2 https://media.neliti.com/media/publications/72177-ID-manajemen-pengelolaan-bank-sampah-dikot.pdf/hal.67- 


\section{Fungsi-fungsi Manajemen}

Fungsi-fungsi manajemen adalah serangkaian kegiatan yang dijalankan dalam manajemen berdasarkan fungsi masingmasing dan mengikuti satu tahapan-tahapan tertentu dalam pelaksanaannya. Fungsi manajemen menurut Nickles and McHugh terdiri dari empat fungsi yaitu: (1) Perencanaan atau Planning. Pengertian Perencanaan Perencanaan merupakan suatu kegiatan yang sistematis, mengenai apa yang akan dicapai, kegiatan yang harus dilakukan, langkah-langkah, metode-metode, dan pelaksanaan tenaga yang dibutuhkan untuk menyelenggarakan kegiatan-kegiatan guna pencapaian tujuan. Perencanaan menempati fungsi pertama dan utama di antara fungsi-fungsi manajemen lainnya. Perencanaan merupakan proses yang menyangkut upaya yang dilakukan untuk mengantisipasi kecenderungan di masa yang akan datang dan penentuan strategi dan taktik yang tepat untuk mewujudkan target dan tujuan organisasi. Dalam menyusun perencanaan, pertama-tama harus ada definisi mengenai visi yang ingin dicapai, kemudian dijabarkan dalam bentuk misi. Jadi, secara defini perencanaan adalah penentuan awal dari arah kegiatan (course of action). Terdapat empat prinsip dalam perencanaan yaitu faktor yang kritis (the critical few), keengganan untuk berubah (resistance to change), kestabilan perencanaan (planning stability) dan keterukuran (tangibility). Jenisjenis Perencanaan sebagai berikut:

1. Perencanaan berdasarkan waktu. Perencanaan berdasarkan waktu dibagi menjadi perencanaan jangan pendek, perencanaan jangka menengah dan perencanaan jangka panjang. Perencanaan jangka pendek (short range) adalah perencanaan yang mencakup waktu kurang dari satu tahun. Perencanaan jangka menengah (intermediate range) adalah perencanaan yang meliputi waktu satu tahun lebih tapi kurang dari lima tahun. Perencanaan jangka panjang (long range) adalah perencanaan yang mencakup waktu lebih dari lima tahun.

2. Perencanaan menurut ruang lingkupnya. Perencanaan menurut ruang lingkupnya terdiri dari perencanaan strategis dan perencanaan operasional. Perencanaan strategis (strategic plan) yaitu rencana yang diterapkan pada organisasi secara keseluruhan dan menetapkan tujuan keseluruhan organisasi Perencanaan strategis biasanya dirancang untuk memenuhi tujuan organisasi yang lebih luas, menetapkan misi yang memberikan alasan khusus tentang keberadaan organisasi.

3. Sedangkan perencanaan operasional (operational plans) yaitu rencana yang menetapkan rincian tentang cara mencapai keseluruhan tujuan organisasi. Perencanaan operasional biasanya dirancang untuk menguraikan lebih spesifik dan terperinci perencanaan strategis, bagaimana rencana rencana strategis akan dicapai. Perecanaan Operasional sebagai berikut:

a. Perencanaan bersifat khusus Perencanaan bersifat khusus terdiri dari perencanaan direksional dan perencanaan spesifik. Perencaanaan direksional yaitu rencana yang fleksibel yang menetapkan pedoman umum bagi para manajer. Rencana direksional berfokus untuk membatasi manajer ke dalam sasaran khusus atau rangkaian tindakan. Sedangkan perencanaan spesifik yaitu rencana yang sudah dirumuskan dengan jelas dan tidak menyediakan ruang untuk interpretasi.

b. Perencanaan berdasarkan frekuensi. Perencanaan berdasarkan frekuensi terdiri dari perencanaan sekali pakai dan perencanaan tetap. Rencana sekali pakai (single use plan) merupakan rencana yang dikembangkan untuk mencapai tujuan tertentu dan tidak akan digunakan kembali setelah rencana tercapai. Sedangkan rencana tetap (standing plans) merupakan pendekatan standar untuk penanganan situasi-situasi yang dapat diperkirakan dan terjadi berulang-ulang. 
(2) Pengorganisasian atau Organizing. Pengertian Pengorganisasian. Pengorganisasian yaitu proses yang menyangkut bagaimana strategi dan taktik yang telah dirumuskan dalam perencanaan didesain dalam sebuah struktur organisasi yang tepat dan tangguh. Menurut John Suprihanto (2014), pengorganisasian merupakan kegiatan menyusun struktur hubungan kerja sehingga anggota organisasi dapat berinteraksi dan bekerja sama untuk mencapai tujuan-tujuan organisasi. Dalam pengorganisasian ini, terdapat dua spek utama dalam prospek penyusunan struktur organisasi yaitu meliputi departementasi dan pembagian kerja. Departementasi merupakan pengelompokan kegiatan-kegiatan kerja suatu organisasi agar kegiatan sejenis dan saling berhubungan dapat dikerjakan bersama. Sedangkan pembagian kerja adalah perincian tugas pekerjaan agar setiap individu dalam organisasi bertanggungjawab untuk melaksanakan sekumpulan kegiatan terbatas. Pengertian dan Jenis-jenis Organisasi. Organisasi berasal dari kata to-organize, yang berarti mengatur atau menyusun bagian-bagian yang terpisah-pisah sehingga menjadi satu kesatuan yang dapat digunakan untuk melakukan pekerjaan. Dalam kegiatan sehari-hari organisasi dapat diartikan sebagai wadah atau tempat di mana dilakukan kegiatan manajerial. Dalam sebuah organisasi terdapat struktur organisasi (design organisation) yang merupakan mekanisme-mekanisme formal mengelola organisasi. Struktur organisasi menunjukkan kerangka dan susunan perwujudan pola tetap hubungan-hubungan di antara fungsi-fungsi, bagian atau posisi dan tugas wewenang yang berbeda dalam suatu organisasi. Organisasi dibedakan menjadi dua, yakni organisasi formal dan organisasi informal. Menurut William G. Scott (1962), organisasi formal adalah suatu sistem mengenai aktivitasaktivitas yang dikoordinasikan dari sekelompok orang yang bekerja sama ke arah suatu tujuan bersama. Sedangkan organisasi informal merupakan kumpulan hubungan antar perseorangan tanpa tujuan bersama yang disadari meskipun pada akhirnya hubungan-hubungan yang tak disadari untuk tujuan bersama. Prinsip-prinsip Organisasi. Prinsip-prinsip organisasi adalah pedoman bagi pendelegasian otoritas. Prinsip dalam organisasi yakni meliputi spesialisasi kegiatan, standarisasi kegiatan, koordinasi kegiatan dan ukuran satuan kerja. Spesialisasi kegiatan berkenaan dengan spesifikasi tugas-tugas individual dan kelompok kerja dalam organisasi (pembagian kerja) dan penyatuan tugas-tugas tersebut menjadi satu kesatuan kerja (departementalisasi). Sedangkan standarisasi kegiatan merupakan prosedur yang digunakan organisasi untuk menjamin terlaksananya kegiatan seperti yang direncanakan. Standarisasi kegiatan merujuk secara formal bahwa sejauh mana suatu pekerjaan di dalam organisasi dibakukan dan sejauh mana tingkah laku karyawan dibimbing oleh peraturan dan prosedur. Standarisasi kegiatan setiap oraganisasi berbeda-beda tergantung kebutuhan organisasi. Koordinasi kegiatan yaitu suatu gambaran yang menunjukkan prosedur-prosedur yang mengintegrasikan fungsi-fungsi satuan kerja dalam organisasi. Koordinasi adalah usaha mengarahkan kegiatan seluruh unit-unit organisasi agar tertuju untuk memberikan sumbangan semaksimal mungkin untuk mencapai tujuan organisai secara menyeluruh. Ukuran satuan kerja yaitu menunjukkan jumlah karyawan dalam suatu kelompok kerja. Ukuran satuan kerja merujuk pada rentang kendali yaitu jumlah karyawan yang dapat disupervisi oleh seorang manajer yang dimiliki oleh sebuah organisasi. Semakin luas rentang kembali maka semakin efisien dalam biaya. Akan tetapi, dalam keadaan tertentu, rentang kendali yang lebih luas dapat mengurangi efektivitas.

(3) Penggerakan atau Actuating. Fungsi penggerakan (actuating) merupakan usaha untuk menciptakan iklim kerja sama di antara staf pelaksana program sehingga tujuan organisasi dapat tercapai secara efektif dan efisien. Fungsi penggerakan tidak terlepas dari fungsi manajemen lainnya. Fungsi penggerak dan pelaksanaan dalam istilah lainnya yaitu membangkitkan motivasi (motivating), memberikan arah (directing), mempengaruhi (influencing), dan memberian komando atau perintah (commanding). Tujuan fungsi penggerakan. Fungsi 
penggerakan haruslah dimulai pada pimpinan organisasi. Seorang pemimpin harus mampu bersikap objektif dalam menghadapi berbagai persoalan organisasi melalui pengamatan, objektif dalam menghadapi perbedaan dan persamaan karakter stafnya baik sebagai individu maupun kelompok manusia. Pemimpin mempunyai tekad untuk mencapai kemajuan, peka terhadap lingkungan dan adanya kemampuan bekerja sama dengan orang lain secara harmonis. Dengan kata lain, pemimpin harus peka dengan kodrat manusia yaitu mempunyai kekuatan dan kelemahan, tidak mungkin akan mampu bekerja sendiri dan pasti akan memerlukan bantuan orang lain. Manusia mempunyai kebutuhan yang bersifat pribadi dan sosial, dan pada diri manusia terkadang muncul juga sifat-sifat emosional. Berikut ini adalah tujuan dari fungsi penggerakan: 1. Menciptakan kerja sama yang lebih efisien; 2. Mengembangkan kemampuan dan keterampilan staf; 3. Menumbuhkan rasa memiliki dan menyukai pekerjaan; 4. Mengusahakan suasana lingkungan kerja yang meningkatkan motivasi dan prestasi kerja staf; 5. Membuat organisasi berkembang secara dinamis. Tahapan Penggerakan. Tindakan penggerakan dibagi dalam tiga tahap, yaitu:

1. Memberikan semangat, motivasi, inspirasi atau dorongan sehingga timbul kesadaran dan kemauan para petugas untuk bekerja dengan baik. Tindakan ini juga disebut motivating.

2. Pemberian bimbingan melalui contoh-contoh tindakan atau teladan. Tindakan ini juga disebut directing yang meliputi beberapa tindakan seperti pengambilan keputusan, mengadakan komunikasi antara pimpinan dan staf, memilih orang-orang yang menjadi anggota kelompok dan memperbaiki sikap, pengetahuan maupun keterampilan staf.

3. Pengarahan (directing atau commanding) yang dilakukan dengan memberikan petunjukpetunjuk yang benar, jelas dan tegas. Segala saran-saran atau instruksi dengan baik terarah kepada tujuan yang telah ditetapkan.

(4) Pengendalian atau Pengawasan (Controlling). Pengendalian atau pengawasan yaitu proses yang dilakukan untuk memastikan seluruh rangkaian kegiatan yang telah direncanakan, diorganisasikan, dan diimplementasikan bisa berjalan sesuai dengan target yang diharapkan, sekalipun berbagai perubahan terjadi dalam lingkungan dunia bisnis yang dihadapi. Dalam pelaksanaan pengawasan, terdapat beberapa prinsip yang merupakan basis dari fondasi pengawan yang baik. Prinsip tersebut meliputi point of control, self control dan personal control. Pengawasan dalam dibagi menjadi dua, yaitu: Pengawasan langsung adalah apabila pimpinan organisasi melakukan sendiri terhadap kegiatan yang sedang dijalankan oleh para bawahannya. Pengawasan langsung dapat berupa inspeksi langsung, pengamatan langsung di tempat, dan membuat laporan di tempat. Pengawasan tidak langsung adalah pengawasan dari jarak jauh. Pengawasan ini dilakukan melalui laporan yang disampaikan oleh para bawahan. Bentukbentuk pengawasan tidak langsung dapat berupa laporan secara lisan, laporan tertulis, dan laporan khusus. Tipe-tipe Pengawasan: Pengawasan Pendahuluan (feed forward control) atau disebut Steering Control, yaitu melakukan antisipasi masalah-masalah atau penyimpangan-penyimpangan dari standar yang dibuat, sebelum tahap kegiatan tertentu diselesaikan. Pengawasan Secara Bersamaan (concurrent control) sering disebut pengawasan Ya-Tidak, yaitu: pengawasan yang dilakukan bersamaan dengan pelaksanaan kegiatan. Tipe pengawasan ini merupakan proses yang harus memenuhi persyaratan sebelum kegiatan dilaksanakan. Pengawasan Umpan Balik (feed back control) atau Past Action Control, yaitu: pengawasan yang dilakukan mengukur hasil-hasil dari suatu kegiatan yang telah selesai. Beberapa literatur mengemukakan pengertian yang berbeda, namun memiliki esensi yang sama. Melalui empat tahap itulah manajemen dapat bergerak dan saling bersinergi, yang tentunya tidak terlepas dari peran seorang manajer. Artinya, proses manajerial sebuah organisasi akan berjalan sesuai dengan tujuan organisasi apabila seorang manajer paham secara benar apa yang dilakukan berdasarkan prinsip POAC dalam manajemen. 


\section{Bank Sampah}

Secara istilah, Bank Sampah terdiri dari dua kata, yaitu Bank dan Sampah. Menurut Undangundang No. 10 tahun 1998 yang dimaksud bank adalah badan usaha yang menghimpun dana dari masyarakat dalam bentuk simpanan dan menyalurkannya kepada masyarakat dalam rangka meningkatkan taraf hidup rakyat banyak. Bank merupakan suatu badan usaha yang tugas utamanya sebagai perantara keuangan dengan menyalurkan dana yang berasal dari pihak yang kelebihan dana (surplus) kepada pihak lain yang membutuhkan dana. Peranan Bank Sampah dapat dilihat dalam teori pertukaran. Menurut Damsar (2010: 62) teori pertukaran melihat dunia ini sebagai pertukaran, tempat orang-orang saling bertukar ganjaran atau hadiah. Asumsi dalam teori pertukaran yaitu: pertama, mempertimbangkan manusia sebagai makhluk rasional, kedua, perilaku pertukaran sosial dapat terjadi bila melalui interaksi dengan orang lain, dan ketiga, transaksi pertukaran terjadi hanya apabila pihak yang terlibat memperoleh keuntungan dari pertukaran.

\section{Komponen-komponen Bank Sampah}

Standar manajemen Bank Sampah merupakan standar minimal yang perlu dilengkapi pada setiap komponen yang terlibat dalam pelaksanaan kegiatan Bank Sampah. Diantaranya yaitu penabung sampah, pelaksana bank sampah dan pengepul.

a. Penabung sampah adalah anggota atau nasabah Bank Sampah. Penabung sampah melakukan upaya pengurangan dan pemilihan sampah di rumah masing-masing serta memiliki buku tabungan sampah (rekening) dan wadah sampah terpilah sedikitnya untuk dua jenis sampah.

b. Pelaksana Bank Sampah adalah Pengelolaan Bank Sampah dilakukan secara sukarela maupun profesional. Kelengkapan struktur dan operator Bank Sampah tergantung pada tingkat perkembangan Bank Sampah. Sehingga struktur dan jumlah pengelola antara Bank Sampah satu dengan yang lain bisa berbeda. Struktur minimal pengelola Bank Sampah terdiri dari lima orang yang terdiri dari direktur atau manajer, bendahara atau bagian akuntansi dan customer service atau teller.

c. Pengepul atau Pembeli sampah Komponen pengepul atau pembeli sampah atau industri daur ulang sebagai pembeli sampah dari pengelola Bank Sampah dipilih secara efektif untuk mendukung upaya peningkatan kualitas lingkungan secara menyeluruh. Selain itu hubungan antara pengelola Bank Sampah dengan pembeli diwujudkan dengan dalam bentuk kerjasama.

\section{METODE PENELITIAN}

Metode yang digunakan dalam penelitian ini adalah metode deskriptif-kualitatif. Metode deskriptif-kualittatif analisis dilakukan dengan cara mendeskripsikan, dengan maksud untuk menemukan unsur-unsurnya kemudian dianalisis bahkan juga diperbandingkan. Sehingga dapat disimpulkan bahwa metode deskriptif adalah sebuah cara atau teknik yang dilakukan untuk memaparkan suatu permasalahan sehingga dapat dengan jelas dianalisis dan ditarik kesimpulan. Adapun tahapan metode penlitian sebagai berikut :

1. Sumber Data terdiri dari data primer (didapatkan melalui wawancara dan survei lansung ke lapangan) dan data sekunder (didapatkan dari kajian-kajian sejenis).

2. Teknik Pengumpulan Data terdiri dari studi kepustakaan (konsep manajemen bank sampah) dan studi lapangan (wawancara dan diskusi dengan pemerintah Desa Gudang Tengah). 
3. Teknik Pembuatan Daftar Pertanyaan. Daftar pertanyaan terdiri dari dua bahasan yaitu: kendala-kendala di lapangan dan solusi pengelolaan sampah DGT dengan manajemen Bank Sampah.

4. Teknik Analisis Data. Data diolah dengan menggunakan metode deskriptif kualitatif, kemudian dari analisis yang telah dilakukan diambil suatu kesimpulan.

5. Diagram Alir Penelitian bisa dilihat pada Gambar 3.

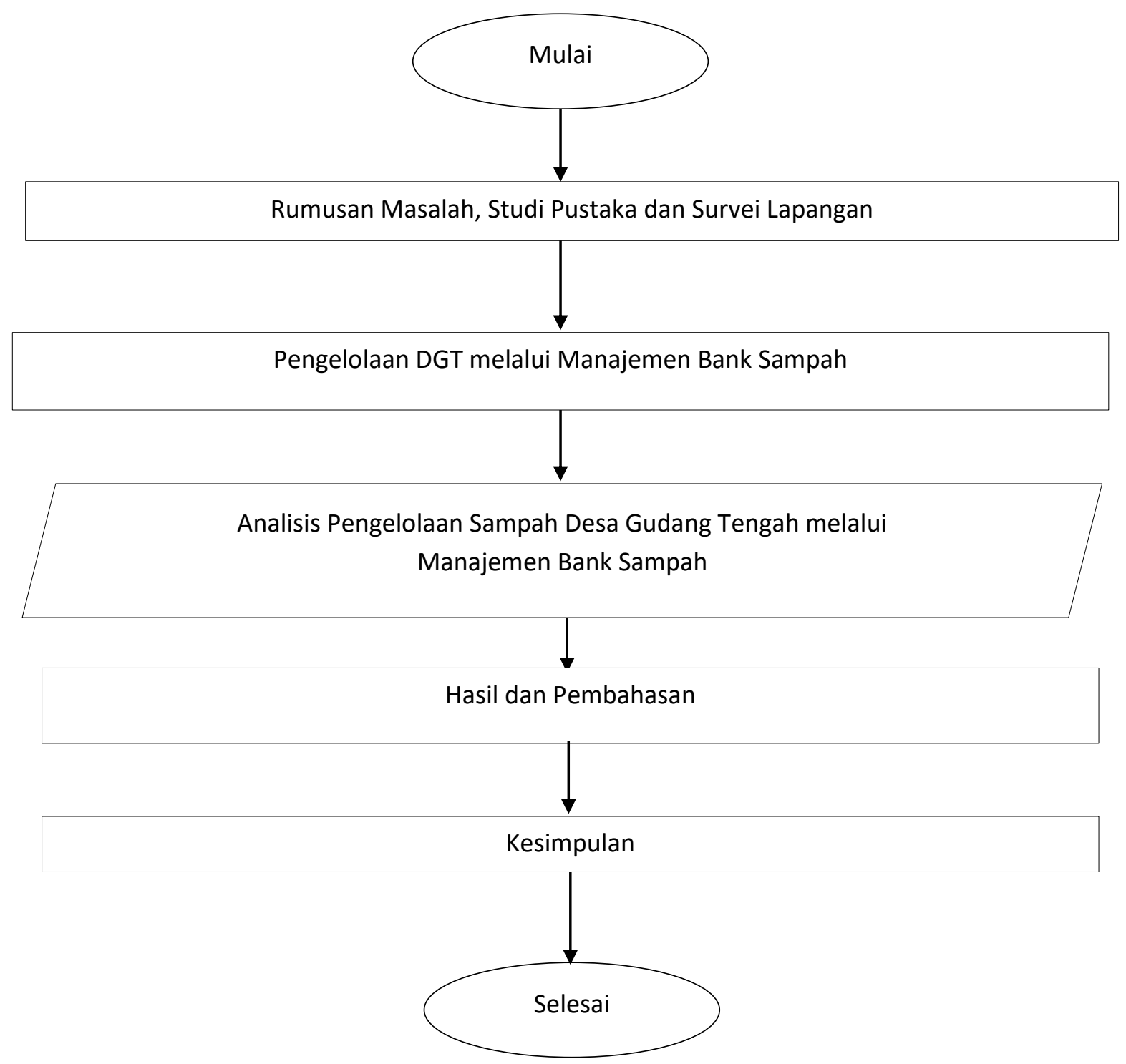

Gambar 3. Diagram Alir Penelitian

Sumber : Analisis, 2019

\section{Mekanisme Bank Sampah}

\section{HASIL DAN PEMBAHASAN}

Bank sampah dalam melaksanakan kegiatan operasionalnya terdapat beberapa tahap, mulai dari pengumpulan, pemilahan hingga pencatatan. Proses tersebut meliputi: 1. Pemilahan sampah rumah tangga oleh nasabah bank sampah; 2. Penyetoran sampah ke bank sampah oleh nasabah bank sampah; 3. Penimbangan, sampah yang sudah ditimbang kemudian ditimbang sesuai dengan kesepakatan minimal; 4. Pencatatan, pencatatan bobot bank sampah setelah 
penimbangan; 5. Hasil sampah dilaporkan kedalam buku tabungan nasabah bank sampah; 6 . Sampah dimanfaatkan untuk dibuat produk kreasi sampah.

\section{Kendala-kendala dalam pengelolaan sampah Desa Gudang Tengah melalui Manajemen Bank Sampah}

Yang menjadi kendala-kendala dalam Penerapan Bank Sampah di Desa Gudang Tengah (dalam diskusi dan wawancara) yaitu :

1. Belum sadarnya masyarakat arti kebersihan lingkungan dan adanya dampak ekonomi langsung apabila mampu mengolah sampah Pasar Desa Gudang Tengah.

2. Belum adanya Bank Sampah, baru proses pembentukan struktur organisasi Bank Sampah, diharapkan bisa bersinergi bersama-sama dengan diterapkannya Konsep $3 \mathrm{R}$ dan Teknologi Lingkungan.

3. Belum memahami konsep manajemen Bank Sampah.

\section{Strategi pengelolaan sampah Desa Gudang Tengah melalui manajemen Bank Sampah}

Tabel 6. Strategi Pengelolaan Sampah Desa Gudang Tengah melalui Manajemen Bank Sampah

\begin{tabular}{|c|l|}
\hline No. & \multicolumn{1}{|c|}{ Tahapan } \\
\hline 1. & $\begin{array}{l}\text { Survei lapangan, tahapan ini mensurvei dan mengumpulkan data bagaimana sampah } \\
\text { Desa Gudang Tengah dikelola dan diolah. Ternyata belum dikelola dan diolah dengan } \\
\text { baik hanya dikumpulkan sampah-sampah tanpa ada pemilahan. Sampah langsung } \\
\text { diangkut ke TPS menggunakan 1 unit tosa }\end{array}$ \\
\hline & \\
\hline
\end{tabular}




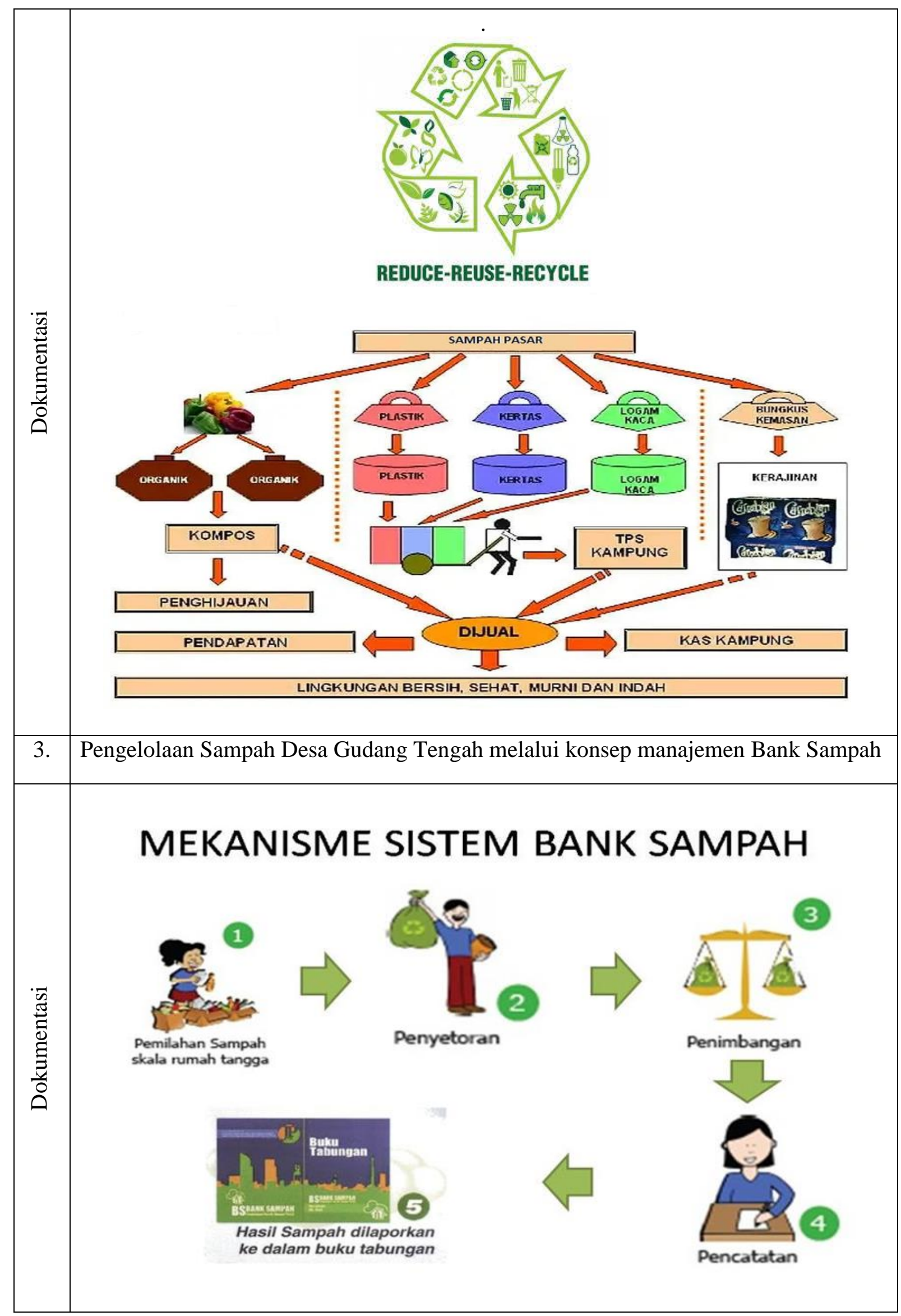


JURNAL KACAPURI

JURNAL KEILMUAN TEKNIK SIPIL

Volume 3 Nomor 1 Edisi Juni 2020

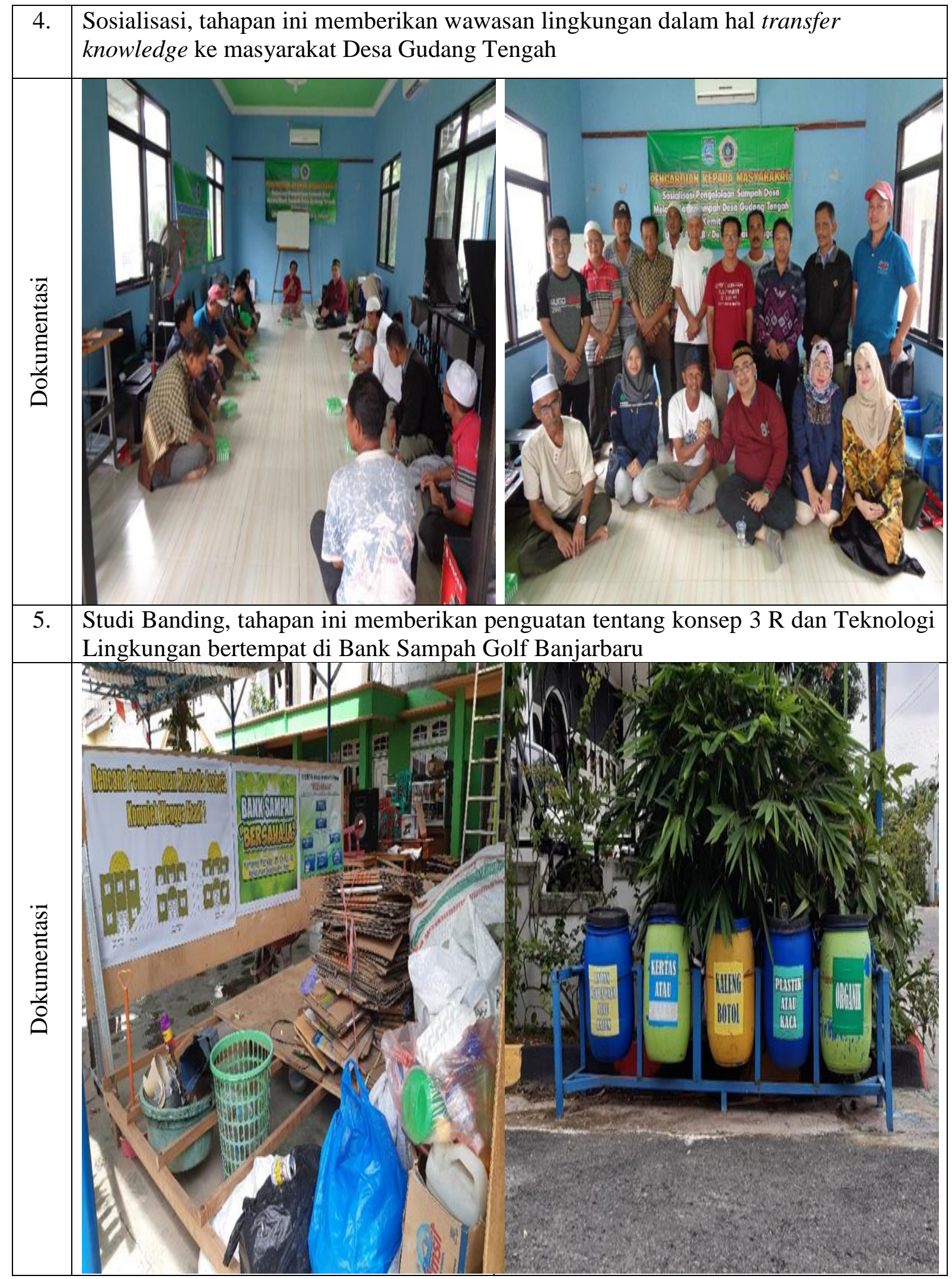

Sumber : Metode deskriptif-kualitatif dan wawancara, 2019. 


\section{PENUTUP}

\section{Kesimpulan}

1. Masyarakat sangat antusias dan menginginkan pengelolaan sampah pasar yang baik berwawasan lingkungan melalui konsep $3 \mathrm{R}$ dan teknologi lingkungan yang diterapkan. Agar lingkungan pasar menjadi bersih dan nyaman serta mendatangkan nilai ekonomis.

2. Masyarakat akan segera membentuk Bank Sampah Desa Gudang Tengah untuk mengurus segala sesuatu berkenaan sampah desa termasuk didalamnya sampah pasar dan sampah rumah tangga.

3. Dengan konsep Manajemen Bank Sampah dapat diterapkan dengan baik, menyadarkan masyarakat bahwa sampah bisa mendatangkan nilai ekonomis dengan menukarkan sampah plastik dengan rupiah per kg melalui Bank Sampah.

4. Perlu kedepannya diberikan pelatihan manajemen organisasi bank sampah untuk meningkatkan produksi (pengumpulan jenis sampah yang bernilai ekonomis) dan penjualan (pengempul sampah yang memberikan daftar harga sampah) yang efektif serta menguntungkan bagi masyarakat.

\section{Ucapan Terimakasih}

Penulis mengucapkan terimakasih kepada program Penelitian Dosen, kawan-kawan dosen Universitas Islam Kalimantan Muhammad Arsyad Al Banjari, Pembakal dan Masyarakata Desa Gudang Tengah, Mahasiswa Uniska MAB serta semua pihak yang telah banyak membantu kelancaran dan selesainya penelitian ini.

\section{DAFTAR PUSTAKA}

Abeng, Tanri, Profesi Manajemen, Jakarta: Gramedia Pustaka Utama Anggota IKAPI, 2006.

Afrizal, Metode Penelitian Kualitatif: Sebuah Upaya Mendukung Penggunaan Penelitian Kualitatif dalam Berbagai Disiplin Ilmu, Jakarta: PT Raja Grafindo, 2016.

Akhtar, H., dan Soetjipto, H.P., Peran Sikap dalam Memediasi Pengaruh Pengetahuan Terhadap Perilaku Minimisasi Sampah Pada Masyarakat Terban, Yogyakarta. Jurnal Manusia dan Lingkungan, 21 (3), Hal.386-392, 2014.

Anonim, Laporan Potensi Desa Gudang Tengah, 2019.

Anonim, Kabupaten Banjar Dalam Angka, 2018.

Anonim, Profil Bank Sampah Indonesia, Kementerian Lingkungan Hidup, Jakarta, 2012.

Asteria, D., Model Komunikasi Lingkungan Berperspektif Gender dalam Menyelesaikan Konflik Lingkungan di Perkotaan: Peran Aktivis Perempuan dalam Pengelolaan Konflik Lingkungan Secara Berkelanjutan. PUPT BOPTN 2013. Universitas Indonesia, Depok, 2013.

Blocker, T.J., dan Eckberg, D.L., Gender and Environmentalism: Result from the 1993 General Social Survey. Social Science Quarterly, 78(4), pp.841-858, 1997.

Choliq, Abdul, Pengantar Manajemen, Yogyakarta: Ombak Dua, 2014. 
Darmawan, Deni, Metode Penelitian Kuantitatif, Bandung: PT Remaja Rosdakarya, 2013.

Hendro, Tri, Conny Tjandra Pahardja, Bank dan Institusi Keuangan Non Bank, Yogyakarta: UPP STIM YKPN, 2014.

Ife, Jim, Frank Tesoriero, Alternatif Pengembangan Masyarakat di Era Globalisas; Community Empowerment, Yogyakarta: Pustaka Pelajar, 2014.

Jumar, Fitriyah, N., dan Kalalinggie, R., Strategi Pengelolaan Sampah Rumah Tangga di Kelurahan Lok Bahu Kecamatan Sungai Kunjang Kota Samarinda. Journal Administrative Reform, 2 (1), Hal.771-782, 2014.

Kristina, H., Model Konseptual Untuk Mengukur Adaptabilitas Bank Sampah di Indonesia. Jurnal Teknik Industri, 9 (1), Hal.19-28, 2014.

Manullang, M., Dasar-dasar Manajemen, Yogyakarta: Gadjah Mada University Pers, 2015.

Ridley-Duff, R.J., dan Bull, M., Understanding Social Enterprise: Theory and Practice, Sage Publication, London, 2011.

Riswan, Sunoko, H.R., dan Hadiyarto, A., Pengelolaan Sampah Rumah Tangga di Kecamatan Daha Selatan. Jurnal Ilmu Lingkungan, 9 (1), Hal. 31-38, 2011.

Robbins, Stephen P., Manajemen, Jakarta: Penerbit Erlangga, 2010.

Sejati, Kuncoro, Pengelolaan Sampah Terpadu, Dengan Sistem Node, Sub Point, Center Point, Yogyakarta: Kanisius, 2009.

Singhirunnusorn, W., Donlakorn, K., dan Kaewhanin, W., Household Recycling Behaviours and Attitudes toward Waste Bank Project: Mahasarakham Municipality. Journal of Asia Behavioural Studies, 2 (6), pp.35-47, 2012.

Sondang, Siagan, Fungsi-fungsi Manajemen, Jakarta: Bumi Aksara, 2016.

Sudaryono, Metodologi Penelitian, Jakarta: PT Raja Grafindo Persada, 2017.

Sugiyono, Metode Penelitian Kuantitatif, Kualitatif dan R\&D, Bandung: Alfabeta, 2012.

Sukandarrumidi, Metodologi Penelitian: Petunjuk Praktis untuk Peneliti Pemula, Yogyakarta: Gadjah Mada University Press Anggota IKAPI, 2012.

Sumaryadi, I Nyoman. 2005. Perencanaan Pembangunan Daerah Otonom dan Pemberdayaan Masyarakat. Jakarta: Penerbit Citra Utama.

Winarso, H., dan Larasati, A., Dari Sampah Menjadi Upah: Inovasi Pengolahan Sampah di Tingkat Akar Rumput Kasus Program Bank Sampah "Sendu" di Kelurahan Pasar Minggu Jakarta Selatan. Jurnal Manusia dan Lingkungan, 18 (1), Hal.43-59, 2011. 